\title{
Supervision and Evaluation of Inclusive Education
}

\author{
Nuphanudin ${ }^{1}$, Aan Komariah ², Dedy Achmad Kurniady3, Camelia Rizki Hana4, \\ Nilam Sukma Pawening5, Tasya Nabilah6, Puteri Azzahrah Madjid7
}

\author{
DOI: $10.35445 /$ alishlah.v13i2.806
}

\begin{abstract}
Article Info
Abstract

Keywords:

Education for all; quality of education; inclusive education; education supervision

This research aims to monitor and evaluate inclusive education and consider strategies that the government can implement. Is it library research thinking was obtained from seven different international research article websites. Article search was prioritized for publications with a timeframe between 2013 and 2021. We got 13 qualitative reviews. The obstacles faced are the common knowledge of educators, inadequate infrastructure, minimal accessibility, and limited learning resources. The strategy carried out is the need for commitment from the authorities to supervise and evaluate inclusive education, which is supported by continuous support from the government during the implementation process in the field. The government's commitment to allocate funding resources and collaboration with other stakeholders is believed to realize education for all.
\end{abstract}

Kata kunci:

Pendidikan untuk

Semua;

kualitas pendidikan; pendidikan inklusif; supervisi pendidikan

\begin{abstract}
Abstrak
Kajian ini bertujuan untuk memantau dan mengevaluasi pendidikan inklusif serta mempertimbangkan strategi yang dapat diterapkan oleh Pemerintah. Pemikiran kritis diperoleh dari tujuh situs artikel penelitian internasional yang berbeda. Pencarian artikel diprioritaskan untuk publikasi dengan rentang waktu antara 2013 dan 2021. Peneliti mendapatkan 13 ulasan kualitatif. Kendala yang dihadapi adalah kesamaan pengetahuan pendidik, sarana prasarana yang belum memadai, aksesibilitas yang minim, dan sumber belajar yang terbatas. Strategi yang dilakukan adalah perlu adanya komitmen dari pihak yang berwenang untuk melakukan supervisi dan evaluasi pendidikan inklusi yang didukung oleh dukungan terus menerus dari Pemerintah selama proses implementasi di lapangan. Komitmen Pemerintah untuk mengalokasikan sumber dana dan kerjasama dengan pemangku kepentingan lainnya diyakini dapat mewujudkan pendidikan untuk semua.
\end{abstract}

1,2,3 Education Administration, Indonesian University of Education, Indonesia

Email: nuphanudin@lecturer.upi.ac.id

4,7 Institute of Domestic Administration, South Sulawesi, Indonesia

5,6 Military Academy, Magelang, Indonesia 


\section{INTRODUCTION}

Supervision in education is structured supervision and guidance activities to improve conditions in an educational institution/school (Bondar and Shestopalova, 2020). As stated by Wiles and Sugg that supervision is an aid in developing better learning situations to help teachers carry out their work. (Wiles and Sugg, 1954; Gordon, 2020). In carrying out supervision of the learning process at school, there are various situations or backgrounds of students' circumstances (Magumise and Sefotho, 2020). One of them relates to the physical and psychological conditions of students. In this case, special efforts are made to get a good education for students with special needs.

Special education for students with special needs has undergone many changes and developments (Makoelle, 2020; Świtała, 2020). Initially, students with special needs took place in Extraordinary Schools (SLB), separate from the community and regular students. SLB-A is for children with visual impairment, SLB-B is for children with hearing impairment, SLB-C is for children with mental retardation, and SLB-D is for children with physical disabilities. However, the existence of SLB is not sufficient to provide the broadest possible access to education for students with special needs equitably and optimally because there are still many students with special needs who are not in school, and this is caused by one of the factors, namely the distance of the school being far from home. -the houses of students with special needs because, in general, SLB is located in the provincial capital and partly in the district/city. Therefore, the government makes a new policy on education that students can take with special needs, namely inclusive education.

In Minister of National Education Regulation No. 70 of 2009 Article 1, Inclusive Education is an education administration system that provides students with disabilities and potential intelligence and unique talents to participate in education or learning in an educational environment and regular students in general. This regulation provides the most comprehensive opportunity for children with special needs to attend any government-approved public school to provide inclusive education. It is emphasized in Article 4 Paragraph 1 that the district/city government establishes at least 1 (one) elementary school, and 1 (one) junior high school in each sub-district, and 1 (one) secondary education unit to provide inclusive education, which is obliged to accept students. As referred to in Article 3 Paragraph 1, every student who has physical, emotional, mental, and social disorders or has the potential for intelligence and unique talents is entitled to participate in inclusive education in specific academic units according to their needs and abilities.

Implementing inclusive education procurement in the field is satisfactory because many public and private schools now provide inclusive education. However, in reality, many schools are still not operationally ready to implement inclusive education. It can be seen from several regional schools in Indonesia; several factors cause inclusive education not to run optimally, namely the lack of understanding of teachers regarding modifying the inclusive education curriculum. (Muh and Uslan, 2020), Inadequate infrastructure (Kurniawati, Setyaninrum and Astutik, 2021), lack of special assistant teachers for students with special needs (Putri, Miarakhman and Krisnawati, 2020), and the national examination assessment system for students with special needs, which is still the same as regular students (Faridi, 2020), and the absence of standard evaluation standards for these students (Alhaddad, 2020).

Based on some of the problems that have been raised, it is necessary to have an in-depth discussion of the supervision and evaluation of the factors that support the process of inclusive education activities in schools that provide inclusive education with government policies by field conditions.

\section{METHODS}

This research is a literature study so that the search for scientific articles is carried out through seven international sites, namely sciencedirect.com, journals.sagepub.com, onlinelibrary.wiley.com, eric.ed.gov, tandfonline.com, springer.com, and scholar. google.com. The research context has been clearly stated as the main reason for selecting articles through the seven 
sites. The search for articles was carried out on July 1-6, 2021. The keywords used were "challenges of inclusive education," and "inclusive education development," and "assessment of inclusive education," with a publication period of 2013 to 2021. While PRISMA -P 2015 was used for data analysis ( Moher et al., 2015; Singh, Kennedy and Stupans, 2019).

The articles selected were based on the following criteria: 1) challenges faced by inclusive schools; 2) barriers faced by inclusive schools; 3) optimization strategy for inclusive education; 4) Qualitative empirical research; 5) English language articles, 6) open access articles, and 7) fully downloadable articles. The scientific article search resulted in 13 out of 61 scientific research articles journals, including nine from sciencedirect.com, one from journals.sagepub.com, one from eric.ed.go, one from springer.com, and one from onlinelibrary.wiley.com . No relevant articles were found on scholar.google.com.

\section{FINDINGS AND DISCUSSION}

\section{Inclusive Education}

Inclusive education is an educational model that includes children with special needs studying with their peers in public schools. In the end, they become part of the school community to create a conducive learning atmosphere (Budiyanto, 2017). Inclusive education here intends as a form of education without discrimination. Children with special needs can study together with children in general in the same school to have no separation between the two. In the end, a conducive learning atmosphere is created.

Meanwhile, other experts define inclusive education as a PLB (Extraordinary education) service system that requires that all ABK (Children with Special Needs) be served at the nearest school in regular classes with their peers. (Budiyanto, 2017). It can be said to be an educational service that provides the most comprehensive opportunity for children with special needs to study with children in general. In addition, Shaeffer in Suyanto defines inclusive education as an educational service that tries to ensure that all students get the right and that all students get a good quality education. (Suyanto, 2007). It means that inclusive education is an education system that ensures that children with special needs get the same rights and quality of education as children in general.

Based on several definitions of inclusive education, experts can conclude that inclusive education is a form of equal education without discrimination between children with special needs and children in general. Both are entitled to receive the same and comparable education in regular classes peers. So, inclusive education can be the most effective tool to build solidarity between children with special needs and peers.

In the Regulation of the Minister of National Education of the Republic of Indonesia Number 70 of 2009 concerning Inclusive Education, it is stated that inclusive education is an education administration system that provides opportunities for all students who have disabilities and have the potential for intelligence and unique talents to attend education or to learn in one environment. Education together with students, in general, has been described. This regulation is a legal basis that states that inclusive education is implemented because children with special needs can get the same education as regular students.

\section{Implementation of Inclusive Education}

Many schools are implementing inclusive education, a form of school compliance with government regulations that require that every school in both districts and cities provide inclusive education at least one school. With the enactment of this, it can be said that the government has succeeded in distributing inclusive education for all students with special needs, where they can study without any obstacles caused by the distance of the school being too far from where they live. Unfortunately, this equitable distribution of inclusive education is not accompanied by equal distribution of quality, both in terms of resources and supporting activities. It can be seen from several previous research results on implementing inclusive education in several regional schools in 
Indonesia (Hastina and Harahap, 2018). His research explains that the implementation of inclusive education cannot run optimally due to several factors. One of them is teachers' understanding regarding the modification of the inclusive education curriculum and inadequate infrastructure (Hastina and Harahap, 2018). In addition to the lack of teacher understanding of the differentiated curriculum and its inadequate facilities and infrastructure, there are still other problems implementing inclusive education (Sartica and Ismanto, 2016). The results of his research explain that in the process of implementing inclusive education, several things are not in line with government laws, one of which is the lack of special assistant teachers for students with special needs and the National Examination system for students with special needs which is still generalized to regular students and there are no standards. Evaluation standard for these students (Sartica and Ismanto, 2016).

\section{Teacher's Understanding of Inchsive Education Curriculum}

One of the problems many countries face when implementing inclusive education is the lack of knowledge among inclusive schools and persons with disabilities. Teachers do not completely understand students with disabilities, such as deaf or blind people (Genova, 2015). In addition, inadequate or ineffective teacher training in inclusive schools is a problem many developing and developed countries still face. The training provided is only a formal test without considering the effectiveness and improvements made after the training (Abongdia, Foncha and Dakada, 2015).

There is a unique context that only occurs in some countries, such as China. According to a survey in China, parents of children with disabilities are pressured by teachers and schools to provide the best education they want, thanks to China's only-child family policy (Jia and Santi, 2020). The family establishes a good education for the child because he is the only child who will determine his fate if he succeeds and will determine the rank of his parents in the future, and it remains to this day. The Chinese believe that parents blame teachers and schools if schools cannot provide the best education for their children because they provide education outside of school for which they are not responsible. It is also the reason behind the discontinuation of teachers who teach children with disabilities. Suppose a teacher makes a mistake or is inappropriate in guiding or teaching children with disabilities, regardless of the teacher's good intentions to provide education and learning for children with disabilities. In that case, the teacher is the parents' fault, when good intentions can become a boomerang for the teacher.

On the other hand, teachers do not understand inclusive schools. They are not trained to provide guidance and appropriate learning resources to children with disabilities, even if available in schools (Jia and Santi, 2020). For this reason, classroom teachers also recommend traditional RCT (Regular Classroom Teacher) education. This training teaches teachers how to incorporate inclusive education and disability-specific knowledge bases, skills needed to meet the learning needs of students with disabilities, resources for disabilities, and the use of appropriate materials available in the knowledge space.

For teachers' understanding of the curriculum used in inclusive education, the Minister of National Education Regulation No. 70 of 2009 Article 7 has explained that the education unit providing inclusive education must use an education unit level curriculum that can accommodate the needs and abilities of students according to their talents and interests (Sartica and Ismanto, 2016). The curriculum referred to here is a differentiated curriculum. Namely, the national curriculum, which is modified according to students with special needs, emphasizes essential material to stimulate and provide a forum for spiritual, logical, ethical, and aesthetic development and creativity of students with special needs.

However, the results of research conducted by Sharma et al. show that teachers do not understand the modification of inclusive education. It is modifying time by adding particular time to repeat/rewind learning materials personally according to students with needs and adjusting the content of the fabric according to the needs of students with special needs. Modifying facilities and infrastructure by changing the sitting rules, composition desks/benches, and the location of the 
blackboard as well as adjusting the learning environment in the classroom and outside the school are conducted to make the teachers are ready to handle students with special needs in their classes, which of course have different characteristics (Sharma et al., 2018). It can be due to the limited ability of teachers, and this happens because teachers have not received practical training and most of the training provided is only limited to socialization so that teachers do not have the appropriate abilities to deal with students with special needs, either from modifying the curriculum and the teaching methods provided still seem rigid and challenging to access for students with special needs, so that learning objectives are not achieved as expected.

\section{Facilities and infrastructure}

The implementation of inclusive education presents unique challenges and obstacles in each region and country. Different countries have different solutions and strategies. Most countries still face several challenges in implementing inclusive schools, including extreme discrimination and negative attitudes such as the perception of persons with disabilities as 'something negative, bad, incomplete, problematic, 'stamp' in life' (Genova, 2015). This further exacerbates the disability situation of persons with disabilities because persons with disabilities carry two burdens at once: the burden of disability and the burden of discrimination against them. In addition to negative attitudes, limited access to public facilities such as toilets, public transportation, and skyscrapers is also a problem for people with disabilities. The lack of ramps/slopes or lifts is an obstacle for people with disabilities and wheelchair users (Bhatnagar and Das, 2014; Genova, 2015). The survey revealed participants' dissatisfaction with the lack of proper public transportation for persons with disabilities due to inconsistencies in government policies to encourage persons with disabilities to work effectively, such as everyone. The government does not provide publicly accessible facilities for persons with disabilities. For them, the policies developed by the government are only political and practical to enable persons with disabilities to function and produce like other ordinary people (Genova, 2015; Kawser, Ahmed and Ahmed, 2016). Discrimination against persons with disabilities still exists in national policies, at the institutional level as a "common thread" between the microlevel (personal experience), intermediaries (national policy) at the central station, and macro (EU 2020 policy on the Continent, for example) (Genova, 2015).

For facilities and infrastructure, in Minister of National Education Regulation No. 70 of 2009 Article 11 Paragraph 2, the Government, regional Government, and the community can provide professional assistance to academic units providing inclusive education. Then, Article 11 Paragraph 4 Point $\mathrm{C}$ explains that professional help is in modifying the curriculum, individual education programs, learning, assessment, media, learning resources, and accessible facilities and infrastructure (Sartica and Ismanto, 2016). The incident in the field still lacks inadequate facilities and infrastructure in schools that provide inclusive education yang (Hastina and Harahap, 2018). It can be seen from the physical condition of the school that is not yet accessible, among others: buildings, school buildings, roads to schools, and classes are still difficult to access for students with special needs, in addition to media or equipment supporting the teaching and learning process such as books in braille, broiler, talking books and special equipment for students are also still rare. The availability of adequate facilities and infrastructure can benefit both students and teachers in the teaching and learning process. For example, in a class with blind students, when the existing facilities are adequate, such as broilers and learning books in braille, the teacher will find it easier to convey the learning material because the teacher can use the broiler to prepare teaching materials for related students. So that teachers do not need to use teaching materials or other teaching methods such as reading texts to these students. This is undoubtedly much more effective for the student's learning process. 


\section{Special Companion Teacher}

The government should provide a Special Assistant Teacher (GPK) ready to handle students with special needs proportionally to every school that provides inclusive education. However, the reality is that there is still a lack of GPK for students with special needs in schools that offer inclusive education, where the number of students with special needs is not balanced with the number of GPK. There are even schools that do not have GPK as the research results conducted by Sartica and Ismanto. Research results show that SDN 6 Bukit Tunggal and SMPN 3 Palangkaraya have organized inclusive education but do not have GPK. This is certainly not in line with Minister of National Education Regulation No. 70 of 2009 article 10 paragraph 1, which states that the district/city government is obliged to provide at least 1 (one) particular supervisor in the education unit designated to provide inclusive education. Minister of National Education Regulation No. 70 of 2009 article 6 paragraphs 1,2, and 3 where district/city governments guarantee the implementation of inclusive education by the needs of children with special needs and ensure the availability of inclusive education resources, and the government and provincial governments assist the availability of inclusive education resources (Sartica and Ismanto, 2016).

Related to the lack of GPK also applies at SDN No. 06499 Medan, there is only one GPK in the school. The background is not from an extraordinary school/education teacher, so the existing teachers still need to attend debriefing and training on understanding how to handle students with special needs according to their needs and can determine appropriate teaching strategies for students with special needs in learning. The lack of special assistant teachers in inclusive classes will impact students' learning process with special needs. When the special assistant teacher does not come to school, students are accidentally neglected. The learning process will not run optimally and effectively.

\section{National Examination System and Evaluation Standards for Students with Special Needs}

The assessment system of the National Examination for students with special needs in the field is an assessment system that is still generalized to regular students. There are no standard evaluation standards for ABK students. The research results conducted by Sartica and Ismanto show that schools still use the same graduation standards for students with special needs as regular students to anticipate and avoid disqualification of students with special needs. Thus, students with special needs are expected to graduate and compete with regular students in the National Examination even though the graduation standards are the same for all students.

This phenomenon is certainly not by Minister of National Education Regulation No. 70 of 2009 Article 9 Paragraphs 2 and 4. It explains that students with special needs who take lessons based on a curriculum according to or above the government's national standards will get a diploma whose blanks are issued by the government. Meanwhile, paragraphs 3 and 5 explain that students with special needs who take lessons based on the curriculum under the national education standard must take exams organized by the school. Suppose the student completes education based on the curriculum developed by the school under the federal education standard. In that case, the student with special needs will receive a letter of completion of study whose form is issued by the school. Meanwhile, what happens is that there is no standard in the learning outcomes of students with special needs, which causes the teacher to make subjective assessments. This, of course, is also not by Minister of National Education Regulation s No. 70 of 2009 article 9 paragraph 1, where "assessment of learning outcomes for inclusive education students refers to the curriculum at the level of the education unit concerned"(Sartica and Ismanto, 2016).

\section{Supervision Planning and Evaluation of Inclusive Education Implementation}

Based on the obstacles that occur in implementing inclusive education policies, it is necessary to supervise and evaluate all the essential elements that support the success of inclusive education. Planning must be systematically structured and consider the interests and abilities of all individuals involved in inclusive education. In the early stages of planning, the main activity that needs to be 
done is to formulate the implementation of supervision and evaluation of the performance of inclusive education itself. The formulation of goals is made so that all activities focus on the goals set to be by what is expected. The objectives that have been formulated are as follows: 1) Ensure that teachers master curriculum modification in inclusive education; 2) Equitable quality GPK in every school that provides inclusive education; 3) Ensure that the facilities and infrastructure in inclusive education are adequate and accessible, and 4) Establish a UN assessment system (National Examination) and clear evaluation standards for students with special needs.

\section{Implementation of the Supervision and Evaluation Program for Inclusive Education}

In implementing the supervision and evaluation of inclusive education in schools, several individuals must be involved. The element that carries out management from outside the school is the supervisor of the education sector, and those who carry out supervision from within the school are the principal, special assistant teachers (GPK), general teachers, and stakeholders. They are all human resources that can support success in the implementation of inclusive education. The performance of this supervision should be carried out once a year so that supervisors know periodically what needs to be improved, and later supervisors will guide schools so that they can create a practical implementation of inclusive education.

In addition, several supporting tools need to be prepared in the implementation of supervision and evaluation of inclusive education, including 1) Design of program supervision and evaluation activities; 2) Reports on the results of school supervision and evaluation that have been carried out previously; 3) Instruments for supervision and evaluation of inclusive education implementation policies, and 4) Recommendations for follow-up plans based on-field findings.

In addition, implementing the evaluation of inclusive education needs to be carried out according to several appropriate stages. The stages carried out are adjusted to objective conditions and accurate data records. Teachers, principals, and supervisors regularly carry out intense communication and coordination. They have important notes as reminders of situations that have previously been evaluated, with the following conditions expected to improve. The following are several stages that need to be carried out in the implementation of the supervision and evaluation of inclusive education;

\section{Early-stage}

At this stage, the supervisor holds a meeting with the principal of the school concerned. The supervisor referred to here is the supervisor in the field of education. This initial meeting is a stage used as a means for supervisors to find out more deeply about the weaknesses and shortcomings of the school concerned in implementing inclusive education. The information obtained by the supervisor at this stage is by using a more in-depth discussion method to the core of the problem.

\section{Implementation Stage}

At this implementation stage, the supervisor observes the implementation of inclusive education in the school concerned. Aspects that supervisors will follow have been listed in the inclusive education implementation instrument that has been designed. Therefore, the observation made by the supervisor refers to the device. The mechanism for implementing inclusive education can be seen in the table below. 
Table 1. Instruments for the Implementation of Inclusive Education

\begin{tabular}{|c|c|c|c|}
\hline No. & Assessment Aspect & Assessment criteria & $\begin{array}{l}\text { Information/ } \\
\text { Activity Proof }\end{array}$ \\
\hline 1 & $\begin{array}{l}\text { How teachers for students } \\
\text { with special needs carry out } \\
\text { many curriculum } \\
\text { modification activities; } \\
\text { A. } 3-4 \text { activities } \\
\text { B. } 2 \text { activities } \\
\text { C. } 1 \text { activity } \\
\text { D. Less than } 1 \text { activity }\end{array}$ & 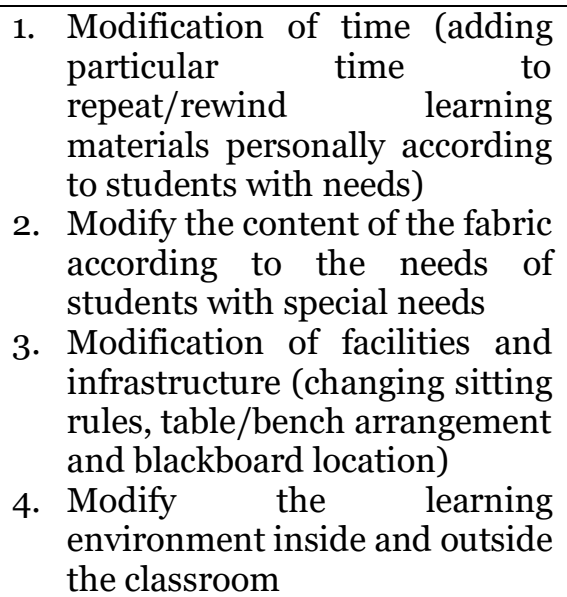 & $\begin{array}{c}\text { Activity } \\
\text { documents }\end{array}$ \\
\hline 2 & $\begin{array}{l}\text { What is the educational } \\
\text { background of GPK at } \\
\text { school? }\end{array}$ & $\begin{array}{l}\text { 1. GPK with undergraduate } \\
\text { education qualifications (S1) } \\
\text { extraordinary education and } \\
\text { has experience in the field } \\
\text { 2. GPK with undergraduate } \\
\text { education qualification (S1) not } \\
\text { from special education but has } \\
\text { received training on inclusive } \\
\text { education } \\
\text { 3. GPK with undergraduate } \\
\text { education qualifications (S1) } \\
\text { are not from special education } \\
\text { and do not know students with } \\
\text { special needs } \\
\text { 4. Non-educational GPK }\end{array}$ & $\begin{array}{c}\text { Written } \\
\text { documents }\end{array}$ \\
\hline 3 & $\begin{array}{l}\text { How often does GPK make } \\
\text { school visits? } \\
\text { A. More than } 2 \text { times a } \\
\text { week } \\
\text { B. } 2 \text { times a week } \\
\text { C. } 1 \text { time a week } \\
\text { D. No GPK } \\
\end{array}$ & $\begin{array}{l}\text { GPK should come to school more } \\
\text { than twice a week so that the } \\
\text { learning process can run effectively } \\
\text { and provide consultative assistance } \\
\text { to regular teachers. And every } \\
\text { student gets optimal learning } \\
\text { assistance }\end{array}$ & $\begin{array}{c}\text { Written } \\
\text { documents }\end{array}$ \\
\hline 4 & $\begin{array}{l}\text { How does GPK provide aid } \\
\text { to schools? }\end{array}$ & $\begin{array}{l}\text { 1. Assist children with special } \\
\text { needs directly (one by one) to } \\
\text { achieve an optimal learning } \\
\text { process } \\
\text { 2. Assisting consultants to } \\
\text { regular teachers }\end{array}$ & $\begin{array}{l}\text { Interview with } \\
\text { GPK }\end{array}$ \\
\hline 5 & $\begin{array}{l}\text { Have all children received } \\
\text { optimal learning } \\
\text { assistance? types of } \\
\text { A. All tisabilities } \\
\text { B. Only some types of } \\
\text { disability } \\
\text { C. Only 1 type of } \\
\text { disability } \\
\text { D. Not at all }\end{array}$ & $\begin{array}{l}\text { All students with special needs with } \\
\text { various types of disabilities receive } \\
\text { optimal learning assistance. } \\
\text { Multiple types of disabilities, } \\
\text { among others, are blind, deaf, } \\
\text { speech impaired, mentally } \\
\text { retarded, physically disabled, } \\
\text { mentally retarded, learning } \\
\text { difficulties, slow learners, autistic, } \\
\text { have motor disorders, victims of } \\
\text { drug abuse, illegal drugs, as well as } \\
\text { other addictive substances and } \\
\text { double blindness. }\end{array}$ & Observation \\
\hline 6 & $\begin{array}{l}\text { Do the facilities and } \\
\text { infrastructure meet the } \\
\text { needs of each crew } \\
\text { member? }\end{array}$ & $\begin{array}{l}\text { The available facilities and } \\
\text { infrastructure can meet the needs } \\
\text { of each student with special needs } \\
\text { with different types of disabilities }\end{array}$ & $\begin{array}{l}\text { Documents for } \\
\text { the use of various } \\
\text { facilities and } \\
\text { physical evidence }\end{array}$ \\
\hline
\end{tabular}




\begin{tabular}{|c|c|c|c|}
\hline & $\begin{array}{l}\text { A. All facilities and } \\
\text { infrastructure complete } \\
\text { B. Only a few facilities and } \\
\text { infrastructure } \\
\text { C. Only } 1 \text { facility and } \\
\text { infrastructure } \\
\text { D. Not at all }\end{array}$ & & \\
\hline 7 & $\begin{array}{l}\text { Does the school implement } \\
\text { a national examination } \\
\text { system for students with } \\
\text { special needs? } \\
\text { A. Applying with an } \\
\text { assessment system as } \\
\text { needed } \\
\text { B. Applying but the } \\
\text { grading system is the } \\
\text { same as regular } \\
\text { students } \\
\text { C. Not applying at all }\end{array}$ & $\begin{array}{l}\text { The school implements the } \\
\text { National Examination (UN) } \\
\text { assessment system with an } \\
\text { assessment format tailored to } \\
\text { students' needs and abilities. }\end{array}$ & $\begin{array}{c}\text { Written } \\
\text { documents } \\
\text { (school } \\
\text { certificate, } \\
\text { question format, } \\
\text { and minutes) }\end{array}$ \\
\hline
\end{tabular}

\section{Final stage}

At this stage, it must be ensured that the supervisor has received the supervision results he has carried out. Furthermore, the supervisor makes another meeting with the principal to convey the results of the care he has encountered by the actual conditions of the school, both satisfactory and unsatisfactory. In delivering the outcomes of care, the supervisor also needs to convey that the assessment is based on several indicators that must be met by the school so that the school can be said to be worthy and good in implementing inclusive education if it meets the intended hands. The following are the indicators, namely;

\section{Content Standard}

a. Indicator 1: every child with special needs (ABK) gets a curriculum that has been developed with an adaptation and modification model as well as an individual learning program model that is by the needs and abilities of children with special needs.

\section{Content Standard}

b. Indicator 2: teachers carry out the learning process by the curriculum and individual education plans (RPI) that are prepared

c. Indicator 3: teachers apply to teach strategies and practices that are tailored to the abilities and needs of each child with special needs

d. Indicator 4: every child with special needs gets assistance from the teacher, GPK, and peers Graduate competence standard

e. Indicator 5: every child with special needs passes the National Examination/School Examination every year.

f. Indicator 6: every child with special needs continues their education to a higher level. Rating Standard

g. Indicator 7: Determination of Graduate Competency Standards (SKL) and Minimum Completeness Criteria (KKM) by the needs and abilities of each child with special needs.

h. Indicator 8: Every child with special needs takes the National Examination and School Examination according to the ability needs of children with special needs. 
i. Indicator 9: Every child with special needs who is declared to have passed the School Exam will receive a Certificate of Study Completion 9 (STTB).

j. Indicator 10: Every once a month, the school reports children's learning outcomes with special needs regularly to parents, which are not only in the form of numbers/scores but are accompanied by several narrative comments.

k. Indicator 11: All parties (teachers, GPK, and parents) are always involved in adjusting/developing children's learning outcomes assessment.

Competency Standards for Teachers and Education Personnel

1. Indicator 12: Representatives of teachers from schools have attended all training on inclusive education and children with special needs.

m. Indicator 13: Regular teachers who have received training have disseminated inclusive education to their peers, communities, and other schools.

n. Indicator 14: GPK that assists inclusive education programs have undergraduate education qualifications $(\mathrm{S} 1)$ in special education and have experience in their field in understanding students with special needs. GPK comes to school more than twice a week and provides consultative assistance to regular teachers. And every student gets optimal learning assistance.

Infrastructure Standards

o. Indicator 15: Learning facilities and infrastructure are available for all types of ABK disabilities.

\section{Management Standard}

p. Indicator 16: Schools are open to accepting all types of disabilities of children with special needs.

q. Indicator 17: There is support from the government in the implementation of inclusive education in schools. And the school has collaborated with higher education levels for the continuation of ABK education.

\section{Financing Standard}

r. Indicator 18: The school incorporates an inclusive education component into the RAPBS/RAKS document every year.

S. Indicator 19: Schools receive and report the systematic use of subsidy funds.

After the supervision results are submitted, the supervisor provides problem-solving, input, and guidance to the school for the obstacles that occur, hoping that there will be improvements in implementing inclusive education in the school concerned.

\section{CONCLUSION}

Inclusive education provided in schools, in principle, aims to achieve equal distribution of education to all students without exception. Educators and all educational stakeholders are increasingly trying to improve the quality and quality of education services proportionally with special needs. Attention and concern for students' diversity of background conditions is positive progress to improve the quality of education. In implementing inclusive education, it is necessary to have a structured and sustainable form of supervision and guidance in every stage carried out. Principals, teachers, supervisors, and elements related to each other are always expected to create a positive, synergistic, and mutually supportive climate, especially in matters directly about ABK students' activities. The role of students in general also dramatically influences the behavior of daily patterns and developments in ABK students.

Inclusive education in schools will run optimally and positively spotlight if the basic principles that serve as standard guidelines are taken seriously. All elements concerned, in this case, the schools, parents, and the government, perform their roles and functions wisely and proportionally. The principle of supervision and guidance and periodic evaluation are expected to be carried out systematically and programmed. All needs for supporting activities and an 
ideal/representative evaluation format are also likely to be available appropriately and adequately. Thus, the series of inclusive education programs implemented in schools can run effectively and produce good quality students and achievers.

\section{REFERENCES}

Abongdia, J.-F. A., Foncha, J. W. and Dakada, A. (2015) "Challenges Encountered by Teachers in Identifying Learners with Learning Barriers: Toward Inclusive Education,” International Journal of Educational Sciences, 8(3), pp. 493-501. doi: 10.1080/09751122.2015.11890271.

Alhaddad, M. R. (2020) "Konsep pendidikan multikultural dan pendidikan inklusif," Jurnal Tarbiyah Islamiyah, 5(1), pp. 21-30. doi: 10.48094/raudhah.v5i1.57.

Bhatnagar, N. and Das, A. (2014) "Regular school teachers' concerns and perceived barriers to implement inclusive education in New Delhi, India,” International Journal of Instruction, 7(2), pp. 89-102.

Bondar, K. and Shestopalova, O. (2020) "Supervision as a model of inclusive education retraining and professional advancement of the school community," SHS Web of Conferences, 75, p. 03012. doi: 10.1051/shsconf/20207503012.

Budiyanto (2017) Pengantar Pendidikan Inklusif Berbasis Budaya Local. Jakarta: Prenamedia Group.

Faridi, F. (2020) “Urgensi Pendidikan Inklusif: Studi Kasus Pada Kegiatan 'B' Religi' di SMA Negeri 3 Kota Malang," J-PAI: Jurnal Pendidikan Agama Islam, 6(2), pp. 119-127. doi: 10.1886o/jpai.v6i2.10125.

Genova, A. (2015) "Barriers to inclusive education in Greece, Spain and Lithuania: results from emancipatory disability research,” Disability and Society, 30(7), pp. 1042-1054. doi: 10.1080/09687599.2015.1075867.

Gordon, S. (2020) "Lessons from the Past: Ideas from Supervision Books Published from 1920 through 1950," Journal of Educational Supervision, 3(2), pp. 51-82. doi: 10.31045/jes.3.2.4.

Hastina, N. and Harahap, D. (2018) "Evaluasi Penyelenggaraan Pendidikan Inklusif bagi Anak Berkebutuhan Khusus di SDN Medan Murelan,” Genta Mulia, IX(1), pp. 1-7.

Jia, L. and Santi, M. (2020) "Chinese regular classroom teachers' understanding of barriers to inclusive education,” Italian Journal of Special Education for Inclusion, 8(1), pp. 218-236. doi: 10.7346/sipes-01-2020-17.

Kawser, U., Ahmed, M. and Ahmed, M. (2016) "Barriers of inclusive education in Bangladesh: Making inclusion a reality," Journal of Social Sciences \& Humanities Research, 2(2), pp. 1-4.

Kurniawati, H., Setyaninrum, I. R. and Astutik, F. A. (2021) "Desain Pendidikan Inklusi Masa Pandemi COVID-19: Studi Kasus di PG TK Alam PATRICK Depok,” Jurnal Dirosah Islamiyah, 3(1), pp. 180-192. doi: 10.17467/jdi.v3i2.394.

Magumise, J. and Sefotho, M. M. (2020) "Parent and teacher perceptions of inclusive education in Zimbabwe," International Journal of Inclusive Education. Taylor \& Francis, 24(5), pp. 544560. doi: 10.1080/13603116.2018.1468497.

Makoelle, T. M. (2020) "Schools' Transition Toward Inclusive Education in Post-Soviet Countries: Selected Cases in Kazakhstan," SAGE Open, 10(2). doi: 10.1177/2158244020926586.

Moher, D. et al. (2015) "Preferred reporting items for systematic review and meta-analysis protocols (prisma-p) 2015 statement," Systematic Reviews, 4(1), pp. 1-9.

Muh, A. S. and Uslan, U. (2020) "Evaluasi Program Pendidikan Inklusi di Sekolah Dasar Abdi Kasih Bangsa," Musamus Journal of Primary Education, 2(2), pp. 102-112. doi: 10.35724/musjpe.v2i2.2536.

Putri, Z. F., Miarakhman, N. F. and Krisnawati, R. D. (2020) "Implementasi kebijakan pendidikan inklusif di SMP Negeri 2 Yogyakarta," Khazanah Intelektual, 4(3), pp. 932-953. 
Sartica, D. and Ismanto, B. (2016) "Evaluasi Penyelenggaraan Program Pendidikan Inklusif Di Kota Palangka Raya 1," Kelola: Jurnal Manajemen Pendidikan, 3(1), p. 49. doi: 10.24246/j.jk.2016.v3.i1.p49-66.

Sharma, U. et al. (2018) "Addressing barriers to implementing inclusive education in the Pacific," International Journal of Inclusive Education, 23(1), pp. 1-14. doi: 10.1080/13603116.2018.1514751.

Singh, H. K., Kennedy, G. A. and Stupans, I. (2019) "A systematic review of pharmacy health coaching and an evaluation of patient outcomes," Research in Social and Administrative Pharmacy. Elsevier, 15(3), pp. 244-251. doi: 10.1016/j.sapharm.2018.04.012.

Suyanto (2007) Pedoman Umum Penyelenggaraan Pendidikan Inklusif. Jakarta: Direktorat Jenderal Mendikdasmen Direktorat Pembinaan Sekolah Luar Biasa.

Świtała, E. (2020) "Inclusive Education in Poland," in Moving towards Inclusive Education. Brill, pp. 38-54. doi: 10.1163/9789004432789_003.

Wiles, K. and Sugg, W. (1954) "Factors influencing curriculum development," Review of Educational Research, 24(3), pp. 195-203. 